\title{
THE CONTACT LENS SOCIETY
}

A NEw Society, purely scientific in object and organisation, has been formed for the study of contact lens work in all its aspects. Members may be medical or non-medical, and it is hoped to stimulate interest in the subject among optical workers, doctors, physiologists and others whose domain touches the question at any point.

The Secretaries of the Society, Mr. A. G. Cross and Mr. G. H. Giles, will be glad to supply information and forms of application for niembership on receipt of a request addressed to 65 , Brook Street, London, W.1.

The first scientfic meeting will be held on January 27, 1947, at 5.30 p.m., at the headquarters of the British Optical Asscciation, 65, Brook Street, London, W.1. Thereafter it is hoped to hold scientific meetings four times a year, or more often if sufficient material is forthcoming.

As will be seen, membership of the Society requires nomination by three members of the Council. For the benefit of those wishing to join, officers of the Society are as follows :-

President: Professor Ida Mlann; Vice-Presidents: Mr. F. A. Williamson-Noble and Mr. K. Clifford Hall; Joint-Secretaries : Mr. A. G. Cross and Mr. G. H. Giles; Treasurer: Mr. C. H. Keeler. Other members of the Council are :-Messrs. J. H. Doggart, G. B. Ebbage, F. Juler, Sir Stewart Duke-Elder, Messrs. F. Dickinson, H. B. Marton. G. I). McKelien and T. Hamblin.

The Rules of the Society are as follows :-

1. Object of, the Society. The object of the Society is the scientific study of contact lens work in all its aspects and the promotion of research into its various problems.

2. Metings. Meetings shall be held as and when the Council deem necessary.

3. Constitution. Membership shall be open to anyone holding a medical or scientific qualification and engaged on work connected with the subject, provided that he is satisfactory to the Council and is willing to declare himself bound by ethical rules of a scientific Society. These are:-

(a) To keep no process or formula secret in any communication.

(b) To allow other members of Society to see records and to repeat experiments.

(c) Not to use membership of the Society as an advertisement.

(d) Not to use the Society as a forum for advertisement of commercial processes or preparations.

(e) To agree to answer to the best of his ability all scientific questions put by fellow members of the Society. 
Such persons shall be ordinary members of the Society. The Council shall be nominated from among the members and shall contain equal numbers of medical and non-medical persons, the latter to include at least one representative of the dispensing opticians. There shall be 14 Founder Members nominated by the Contact Lens Sub-Committee of the Faculty of Opthalmologists. They shall retire at the end of two years and subsequently annually, and shall be eligible for re-election at the Annual General Meeting.

4. Officers of the Society. The officers of the Society shall consist of a President, two Vice-Presidents, two Hon. Secretaries, an Hon. Treasurer and not less than eight other members of the Council.

5. Election of Officers. The officers of the Society shall be elected yearly by ballot, after the first two years, at the Annual General Meeting. A balloting list of the names recommended by the Council, from their number, for election shall be posted to each member two weeks previously.

6. Admission of Members. Subsequent members shall be proposed by three or more members, but can only be admitted by a unanimous vote of the Council. Applicant should state the nature of his connection with and interest in contact lens work, and his intention to abide by the ethical rules of the Society.

7. Subscriptions. The annual subscription shall be initially $£ 1$ 1s. 0d. per year. Any member whose subscription is twelve months in arrears shall, at the discretion of the Council, cease to be a member of the Society.

8. Duties of Officers. The President shall regulate the proceedings of the Society and Council and enforce observance of the rules.

One of the Vice-Presidents shall deputise for the President in his absence.

The Hon. Secretaries shall conduct correspondence, keep minutes of meetings, notify new members of their election, notify the Hon. Treasurer-of resignations or death or changes of address. They shall arrange the meetings with the President, and shall arrange for the publication of papers communicated, subject to agreement with an Editorial Committee.

The Hon. Treasurer shall receive money, make payments and keep accounts. The accounts shall be audited and presented at the Annual General Meeting. The Auditors shall be nominated at the Annual General Meeting.

9. Meetings of Council. Council shall meet as and when deemed necessary and not less than three times per year. Five members shall constitute a quorum. The President shall have a casting vote in addition to his ordinary vote. The Council shall decide upon all questions relating to publications and communications and shall have 
power to submit any paper to referees. A summary of all intended communications must be submitted to the Council before being read.

10. Vacancies of Officers. Vacancies on the Council may be filled by co-option during a current year and by nomination and election at the Annual General Meeting.

11. Publication of Papers. After being passed by the Council, publications may be submitted to the appropriate journals by the author and Hon. Secretaries in consultation.

12. Notice of Meetings. One month's notice of meetings shall be sent to each member.

13. Visitors. No representatives of the press shall be admitted. Each member may bring one visitor to one meeting only.

14. Funds. It shall be in the power of the Council to allocate grants from the funds of the Society for research, but such grants must be approved by a General Meeting of the Society.

\section{BOOK NOTICES}

Physiologie Oculaire Clinique. By A. Magitot. Editors: Masson et Cie, Paris. Pp. 458, with 235 figures. 1946.

Ophthalmologists in every country in the world will be interested to know of a book on the physiology of the eye written by Magitot of Paris, for in our generation he is one of the few masters in this branch of our subject who has spent a great part of his life exploring its many, illusive and fascinating problems. For a quarter of a century he has been a systematic explorer in this wide field and whenever questions arise regarding the intra-ocular pressure, the ocular circulation or the reflexes governing the activities of the eyes, the opinions of Magitot must always be consulted and are usually respected. It is good that he has had the opportunity to set out and analyse our knowledge as it stands to-day in a comprehensive and authoritative volume which will disappoint few who read and study its pages,

In its scope the book is comprehensive and takes in all aspects of the physiology of the visual system-the eye, its central connections and the higher perceptual centres. The first chapter deals with the protective mechanism - the lids and lacrimal apparatus; the second with the sensory (trigeminal) mechanism. The following three chapters deal with the nutrition of the eyes, the vascular circulation, the nature of the aqueous and vitreous, and the factors controlling the intra-ocular tension. In view of Magitot's classical contributions to this subject it is not surprising that these are among the fullest and best chapters in the book. The theory of dialysation of the 